\title{
Peran lembaga perkreditan desa bagi anggota pada masa pandemi Covid-19
}

\author{
I Wayan Ruspendi Junaedi* \\ Universitas Dhyana Pura, Jalan Raya Padang Luwih, Tegal Jaya, Kuta, Badung, Bali 80361, \\ Indonesia \\ ruspendijunaedi@undhirabali.ac.id \\ Donald Samuel Slamet Santosa \\ President University, Jalan Ki Hadjar Dewantara, Cikarang, Bekasi, 17550, Indonesia \\ dsamuel@president.ac.id

\section{Dermawan Waruwu} \\ Universitas Dhyana Pura, Jalan Raya Padang Luwih, Tegal Jaya, Kuta, Badung, Bali 80361, \\ Indonesia \\ dermawanwaruwu@undhirabali.ac.id \\ *Penulis Korespondensi
}

Submitted: Aug 28, 2020; Reviewed: Sep 14, 2020; Accepted: May 04, 2021

\begin{abstract}
This study analyzes the role of village credit institutions (in Indonesian is abberviated LPD) for members during the Covid-19 pandemic. This research is a qualitative phenomenological research. The research was conducted during the Covid-19 pandemic due to observance of health protocols. Research data were collected from primary sources (research informants) with interview techniques, observation, and focus group discussion. The data collected was validated by triangulation of sources and methods. The data were then analyzed using the Spradly domain model analysis technique. The results of the study found three LPD roles for members during the Covid-19 pandemic as follows: (1) productive roles: financial solutions for members based on kinship principles; (2) the role of macro social responsibility: resources for the collective collective of members; (3) the role of micro social responsibility: resources for the needs of individual members.
\end{abstract}

Keywords: covid-19; management; members; role of LPD

\begin{abstract}
Abstrak: Studi ini bertujuan untuk menganalisis peran lembaga perkreditan desa (LPD) bagi anggota pada masa pandemi Covid-19. Penelitian ini adalah penelitian kualitatif fenomenologi. Penelitian dilakukan pada masa pandemi Covid-19 dengan memerhatikan protokol kesehatan. Data penelitian dikumpulkan dari sumber primer (informan penelitian) dengan teknik wawancara, observasi, dan focus group discussion. Data yang terkumpul divalidasi dengan triangulasi sumber dan metode. Data kemudian dianalisis dengan teknik analisis domain model Spradly. Hasil penelitian menemukan tiga peran LPD bagi anggota pada masa pandemi Covid-19 sebagai berikut: (1) peran produktif: solusi keuangan bagi anggota berbasis asas kekeluargaan; (2) peran tanggung jawab sosial makro: sumber pendanaan bagi kebutuhan kolektif anggota; (3) peran tanggung jawab sosial mikro: sumber pendanaan bagi kebutuhan individu anggota.
\end{abstract}

Kata kunci: anggota; covid-19; pengurus; peran LPD 


\section{PENDAHULUAN}

Teori ekonomi mikro menitikberatkan pada peran harga sebagai determinan utama dalam permintaan dan penawaran. Jumlah barang atau jasa yang diminta maupun ditawarkan sangat bergantung pada tingkat harga yang berlaku (Pindyck \& Rubinfeld, 2018). Apabila harga naik, maka jumlah yang diminta akan turun, demikian pula sebaliknya jika harga turun, maka jumlah yang diminta akan naik. Hal ini terkait dengan hukum permintaan (Todaro \& Smith, 2012). Hal ini terjadi pada hampir semua komoditas barang dan jasa yang ditransaksikan. Tak terkecuali dalam hal pasar uang, uang menjadi barang yang ditransaksikan oleh pembeli dan penjual. Pasar uang merujuk pada pertemuan antara permintaan uang dengan penawaran uang. Permintaan uang (MD) berasal dari pihak yang membutuhkan uang, sedangkan penawaran uang (MS) berasal dari pihak yang berkelebihan uang (Staker, 2018). Pihak yang membutuhkan uang mendapatkan pinjaman uang dari pihak yang kelebihan uang. Sebagai balas jasa atas peminjaman ini, maka pihak yang membutuhkan uang akan memberikan imbal balik berupa bunga yang dibayarkan kepada pihak yang meminjamkan uang.

Mekanisme simpan pinjam dalam pasar uang sering kali diperantarai oleh lembaga keuangan. Dalam hal ini, lembaga keuangan menghimpun dana dari pihak yang berkelebihan uang (lending function) dalam bentuk simpanan untuk disalurkan kepada pihak yang membutuhkan uang (funding function) dalam bentuk pinjaman (Nassiri, 2020). Bunga yang dibayarkan dari para peminjam dana, oleh lembaga keuangan kemudian disalurkan kepada penyimpan dana dengan dikurangi keuntungan bagi lembaga keuangan. Lembaga keuangan dapat berbentuk lembaga keuangan bank dan lembaga keuangan non-bank (Hashimoto \& Krogstrup, 2019). Setiap bentuk lembaga keuangan memiliki aturan masing-masing dan bekerja dengan cara masing-masing.

Salah satu lembaga keuangan yang banyak diikuti oleh masyarakat dari Provinsi Bali adalah lembaga perkreditan desa (LPD). LPD mengadopsi model koperasi Raiffeisen (Kaltenborn, 2018). Oleh karena itu, tujuan dari LPD sama dengan tujuan dari koperasi pada umumnya, yaitu untuk menyejahterakan anggotanya (Sattar, 2017). Selain itu, LPD juga dimiliki dan dikelola oleh anggotanya. Oleh karena itu, pihak yang terlibat dalam kegiatan LPD adalah anggota, termasuk di dalamnya anggota menjadi penyimpan dana dan peminjam dana.

Meski dimiliki oleh anggota dan bertujuan untuk menyejahterakan anggota, LPD justru memberikan bunga simpanan yang rendah bagi para anggota dan memungut bunga pinjaman yang tinggi. Kondisi tersebut terjadi ketika dibandingkan dengan bank konvensional yang juga beroperasi di Provinsi Bali. Dengan asumsi ceteris paribus (hal-hal lain dianggap tetap), perilaku konsumen mestinya dikendalikan oleh harga. Oleh karena itu, semestinya orang-orang yang berkelebihan dana akan memilih bunga yang tinggi untuk menyimpan dananya, sedangkan orang-orang yang membutuhkan dana akan memilih bunga yang rendah untuk meminjam dana.

Teori harga yang telah dikemukakan tersebut ternyata tidak terjadi di LPD. Dengan bunga simpanan yang rendah dan bunga pinjaman yang tinggi, masyarakat di Provinsi Bali justru lebih tertarik untuk menyimpan uangnya di LPD, dan apabila membutuhkan dana, mereka juga lebih tertarik untuk meminjam dana di LPD. Hal ini dibuktikan dari hasil wawancara pendahuluan terhadap tujuh anggota LPD di Kabupaten Badung, Provinsi Bali.

Hasil wawancara menunjukkan bahwa anggota-anggota LPD memiliki simpanan maupun pinjaman di LPD. Keberadaan bank konvensional di dekat rumah mereka tidak menjadikan mereka untuk mengalihkan simpanan dan pinjamannya ke bank konvensional. Bahkan, lima dari informan menyatakan bahwa mereka tidak memiliki rekening di lembaga keuangan lain, selain LPD, sedangkan di sisi lain mereka mengetahui bahwa bunga simpanan yang ditawarkan lebih tinggi dan bunga pinjaman yang dibebankan lebih rendah.

Sejak pandemi Covid-19, Bali menjadi salah satu daerah yang paling terdampak secara ekonomi. Sektor pariwisata yang menjadi andalan tidak lagi dapat berjalan dengan baik akibat adanya pembatasan sosial dan larangan untuk berwisata, padahal sektor pariwisata dapat menunjang perekonomian masyarakat Bali khususnya dan Indonesia pada umumnya (Waruwu, 2018). Hal ini berdampak pada industri pariwisata dan industri-industri turunannya, seperti hospitality industry dan culinary industry. Usaha dari sebagian anggota LPD tidak berjalan dengan baik, bahkan sebagian yang lain terpaksa harus menutup usahanya. Berkurangnya pendapatan menjadi dampak yang paling dirasakan oleh para informan. Hal ini karena sektor bisnis yang dikembangkan oleh para informan merupakan bisnis-bisnis yang menjadi turunan dari industri pariwisata. 
Meski demikian, tidak ada seorangpun informan yang berniat untuk memindahkan utangnya ke bank konvensional yang memiliki bunga yang lebih rendah. Mereka memilih untuk tetap meneruskan utangnya di LPD dan mencari jalan lain untuk dapat terus menjalankan kewajibannya untuk mebayar utang, misalnya restrukturisasi utang. Kenyataan yang tidak sesuai dengan teori tersebut membuat lembaga LPD ini menarik untuk dikaji. Supaya kajian dapat dipertanggungjawabkan secara ilmiah, maka kajian dilakukan melalui penelitian. Tujuan dari penelitian ini adalah menganalisis peran LPD bagi anggota, yang akan difokuskan pada masa pandemi Covid-19.

\section{METODE}

Penelitian ini adalah penelitian kualitatif yang melakukan wawancara mendalam dengan teknik triangulasi (Hennink et al., 2020). Hal ini dipilih supaya penelitian dapat mengkaji secara mendalam peran LPD. Selanjutnya, pendekatan yang dipilih adalah fenomenologi (Farid \& Adib, 2018), karena penelitian ini akan berfokus pada peran LPD pada masa pandemi Covid-19, yang saat ini sedang menjadi fenomena global dan cukup berdampak bagi perekonomian Provinsi Bali.

Data penelitian berupa data kualitatif yang dikumpulkan langsung dari sumber primer. Teknik pengumpulan data dilakukan secara observasi, wawancara, dan studi pustaka. Observasi dilakukan dengan cara mengamati kehidupan anggota dan pengurus (pengelola) LPD dan diwawancarai secara mendalam yang menggunakan metode bola salju sampai pada titik jenuh penelitian terkait peran LPD dan dampak pandemi Covid-19. Setelah terkumpul, data kemudian dianalisis dan disusun sesuai polapola yang diinginkan sehingga mudah dipahami oleh pembaca (Sugiyono, 2011). Jumlah informan tidak ditentukan di awal, namun akan berkembang hingga data yang dikumpulkan dirasa mencukupi. Informan penelitian ini berasal dari Kabupaten Badung dan Kabupaten Jembrana. Data dikumpulkan pada saat pandemi Covid-19 terjadi (bulan April-Mei 2020).

Data dikumpulkan dengan teknik wawancara, observasi, dan focus group discussion. Peneliti menjadi instrumen penelitian dan dibantu dengan pedoman wawancara (yang berisikan daftar pertanyaan terbuka), pedoman observasi, dan pedoman focus group discussion. Pengumpulan data dilakukan dengan tetap menerapkan social distancing dan protokol kesehatan. Data yang terkumpul divalidasi dengan triangulasi sumber dan metode. Data yang diperoleh dari sumber yang satu akan diperiksa kebenarannya dari sumber yang lain. Selanjutnya, data yang dihasilkan dari satu teknik pengumpulan data kemudian diperiksa kebenarannya dari teknik pengumpulan data yang lain. Data yang terkumpul kemudian dianalisis dengan teknik analisis domain model Spradley (Sugiyono, 2011). Data dikelompokkan ke dalam domain-domain tertentu. Domain-domain merupakan inti dari peran yang dilakukan LPD kepada para pengurus dan anggotanya pada masa pandemi Covid-19.

\section{HASIL DAN PEMBAHASAN}

Lembaga Perkreditan Desa (LPD) secara umum belum jelas apakah masuk ke dalam lembaga keuangan mikro ataupun lembaga keuangan makro. LPD bergerak berdasarkan payung hukum peraturan daerah, yaitu Keputusan Gubernur Provinsi Bali Nomor 972 Tahun 1984. Selanjutnya, landasan hukum LPD dikuatkan dengan peraturan daerah, yaitu Perda Provinsi Bali Nomor 8 Tahun 2002 tentang Lembaga Perkreditan Desa yang ditetapkan pada 12 September 2002 yang kemudian mengalami perubahan dan yang terakhir adalah Perda Bali Nomor 3 Tahun 2017 (Perda Bali, 2017).

Sebagaimana biasanya dalam pembentukan sebuah organisasi, maka organisasi tersebut memiliki fungsi dan tujuan yang ingin dicapai.

1. Sebagai wadah kekayaan desa yang berupa uang atau surat-surat berharga lainya.

2. Sebagai salah satu Krama Desa Pakraman (lembaga usaha milik desa adat) yang diarahkan pada usaha-usaha peningkatan taraf hidup karma desa dan menunjang pembangunan desa adat.

3. Mendorong pembangunan dan menjaga ketahanan ekonomi krama desa adat melalui tabungan yang terarah serta penyaluran modal yang efektif (Wedayani \& Jati, 2012).

4. Memberantas ijon, gadai gelap, dan lain-lain yang sering terjadi di masyarakat (Sarifah, 2019).

5. Menciptakan pemerataan dan kesempatan berusaha bagi warga desa dan tenaga kerja di pedesaan. 
6. Meningkatkan daya beli serta melancarkan lalu lintas pembayaran dan peredaran uang di desa (Satria \& Parwata, 2018).

7. Melestarikan budaya, adat, dan agama Hindu.

Dilihat dari sisi operasionalnya, keberadaan LPD akan sangat membantu masyarakat dari dua sisi, yaitu secara ekonomi dan secara sosial. Individu maupun kelompok organisasi berperan penting untuk melakukan sesuatu terhadap masyarakatnya, sehingga terwujud pelaksanaan antara hak dan kewajiban (Soekanto, 2005). Secara ekonomis bagi masyarakat yang memiliki keuangan, maka LPD menjadi salah satu alternatif untuk menyimpan dananya dan dapat digunakan secara produktif karena mendapatkan bunga secara bersaing (Putrayasa, 2018). Untuk masyarakat yang membutuhkan dana, maka LPD dapat digunakan sebagai lembaga pemberi pinjaman kepada masyarakat (Darmayani et al., 2017). Sisi sosialnya yaitu sesuai dengan peraturan daerah, maka LPD memberikan keuntungannya sebanyak 20 persen untuk pembangunan desa dan 5 persen lainnya digunakan untuk dana sosial. Fungsi sosial ini dapat meringankan masyarakat dari terbebannya iuran desa dan iuran sosial lainnya, sehingga secara langsung masyarakat bisa mengalokasikan keuangan lainnya untuk keperluan seharihari.

Penelitian telah dilakukan dan menghasilkan data penelitian. Data penelitian juga telah dianalisis, sehingga terbentuklah domain-domain yang merupakan peran dari LPD bagi para pengurus dan anggota pada masa pandemi Covid-19. Sajian dalam bagian berikut akan mengarah langsung kepada berbagai peran LPD yang akan diikuti penjelasan yang berasal dari data penelitian yang telah terkumpul.

Pandemi Covid-19 memberikan dampak negatif terhadap ekonomi para informan penelitian ini. Baik informan yang merupakan anggota LPD maupun informan yang merupakan pengurus LPD, sama-sama terkena dampak dari pandemi Covid-19. Meski demikian, tidak semua dampak yang dirasakan dipandang secara negatif. Terdapat sebagian hal yang dipandang secara positif, baik oleh pengurus dan anggota maupun pengelola.

Pandemi Covid-19 ini tidak memengaruhi LPD di Bali, seperti yang dilansir media (Bali Bank News, 2020), bahkan trennya naik, yaitu LPD Adat Balasinga naik asetnya sebanyak Rp 27,1 miliar, LPD Angantaka Rp 24,5 miliar, dan LPD Tabanan Rp 1,9 triliun (sebelumnya berjumlah Rp 1,8 triliun). Data tersebut menunjukan bahwa LPD memiliki daya tahan yang kuat karena memiliki kepercayaan dari masyarakat Bali pada umumnya dan keterlibatan LPD dalam pembangunan desa.

Berdasarkan hasil penelitian yang telah dilakukan, berikut ini adalah peran dari LPD bagi para pengurus dan anggota pada masa pandemi Covid-19.

\section{Peran produktif: Solusi keuangan bagi anggota berbasis asas kekeluargaan}

Sebagai lembaga yang dimiliki oleh pengurus dan anggota, LPD berperan untuk menyejahterakan pemiliknya, yang dalam hal ini adalah pengurus dan anggotanya. Supaya dapat menyejahterakan pemilik, LPD harus melakukan kegiatan produktif yang berorientasi pada profit lembaga. Sebagaimana lembaga keuangan pada umumnya, profit LPD diperoleh dari selisih antara bunga simpanan dan bunga pinjaman. Selanjutnya dalam asas kekeluargaan, keputusan-keputusan yang diambil dalam LPD merupakan keputusan dari pengurus dan anggota. Informan penelitian menunjukkan bahwa rendahnya bunga simpanan dan tingginya bunga pinjaman merupakan hasil keputusan bersama dengan didasarkan pada asas kekeluargaan. Untuk itulah, maka pengurus dan anggota tetap mendahulukan LPD sebagai solusi keuangan mereka dibandingkan mereka harus menggunakan jasa bank konvensional. Konsep handarbeni atau rasa memiliki senantiasa tertanam dalam benak pengurus dan anggota, yang membuat pengurus dan anggota menjadi loyal terhadap LPD. Pada masa pandemi Covid-19, sebagian pengurus dan anggota mengalami kesulitan keuangan, dan berdampak pada gagal bayarnya kredit yang sedang diambil. Masalah ini kemudian dibawa di rapat pengurus dan anggota. Secara mengejutkan, keputusan rapat pengurus dan anggota cenderung berpihak pada pengurus dan anggota yang terdampak. Pengurus-pengurus dan anggota-anggota tersebut diberikan keringanan dan kemudahan dalam membayar cicilan pinjaman melalui berbagai skema, seperti restrukturisasi utang, penangguhan pembayaran pokok angsuran, hingga pembebasan sementara dari tanggung jawab mengangsur. Di sisi lain, pengurus-pengurus dan anggota-anggota yang berkelebihan dana atau yang tidak terdampak Covid-19 dengan sukarela membantu penyelamatan lembaga (memertahankan profit) yang juga dilakukan dalam berbagai skema, seperti meningkatkan simpanan, meningkatkan pinjaman, bahkan mempercepat pelunasan utang. Pengurus- 
pengurus dan anggota-anggota ini melakukan upaya secara sukarela dengan dasar pikiran bahwa pengurus-pengurus dan anggota-anggota lain yang terdampak Covid-19 dianggap seperti keluarga sendiri yang perlu dibantu dengan jalan melalui LPD. Hal ini tentu sesuai dengan tujuan koperasi pada umumnya. Skema yang digunakan oleh LPD maupun pengurus dan anggota berbeda-beda, bergantung pada permasalahan yang dihadapi.

\section{Peran tanggung jawab sosial makro: Sumber pendanaan bagi kebutuhan kolektif pengurus dan anggota}

Informan-informan dalam penelitian ini menjadi pengurus dan anggota dari LPD yang ada di desa. Pada desa-desa yang ada di provinsi Bali, terdapat kebutuhan-kebutuhan kolektif masyarakat desa. Kebutuhan tersebut utamanya adalah perawatan pura desa, perawatan infrastruktur desa (jalan, saluran air, dan sebagainya), serta keamanan desa. Profit yang telah dihasilkan dari peran pertama (peran produktif) kemudian digunakan untuk kepentingan sosial secara kolektif. Profit tersebut diperoleh dari hasil usaha dikurangi dengan operasional LPD (misalnya honor pengurus, listrik, air, dan sebagainya). Dalam hal ini, profit LPD salah satunya digunakan untuk merawat pura yang ada di desa. Komponen ini meliputi pengeluaran rutin seperti pengadaan sesaji, kebersihan pura, perawatan bangunan, serta pengeluaran tidak rutin seperti pemugaran bangunan hingga pengadaan atau pembangunan pura baru. Hal ini dilakukan supaya masyarakat desa (yang juga pengurus dan anggota LPD) dapat beribadah dengan baik. Selain itu, profit LPD juga digunakan untuk perawatan infrastruktur desa, yang bukan menjadi tanggung jawab pemerintah. Dana profit LPD menjangkau infrastruktur desa yang belum tersentuh dana dari pemerintah desa, sehingga bersifat sebagai pelengkap dana desa. Organisasi merupakan sebuah sistem keyakinan, nilai-nilai, dan norma dalam bertingkah laku dan mengembangkan potensi masyarakatnya (Widyastuti et al., 2017). Informan dari salah satu desa memaparkan bahwa untuk jalan desa dan saluran air dibangun dari dana desa, sedangkan perawatan jalan dan saluran air tersebut didanai dari profit LPD. Dengan demikian, masyarakat yang melalui jalan dan menggunakan saluran air untuk irigasi akan merasa nyaman. Selain ibadah dan infrastruktur, profit LPD juga digunakan untuk menjamin keamanan dan kenyamanan psikologis pengurus dan anggota atau warga desa. Pada setiap desa yang diteliti, terdapat petugas keamanan desa yang disebut sebagai pecalang. Tugas dari pecalang ini adalah menjaga keamanan desa. Supaya pecalang dapat bertugas secara maksimal, maka pecalang mendapatkan penghasilan dari LPD. Dengan adanya pecalang ini, masyarakat maupun pengurus dan anggota LPD merasakan keamanan di desanya. Pada masa pandemi Covid-19, tingkat keamanan di daerah-daerah lain menjadi memprihatinkan. Hal ini sebagai imbas dari hilangnya atau berkurangnya pendapatan masyarakat. Akhirnya, masyarakat memilih untuk berbuat kriminal demi memenuhi kebutuhan hidupnya. Secara mengejutkan, hal ini tidak terjadi di Bali. Angka kriminalitas memang meningkat, namun tidak sampai pada taraf yang membahayakan. Hal ini tentu tidak lepas dari peran pecalang yang ada di Bali.

\section{Peran tanggung jawab sosial mikro: Sumber pendanaan bagi kebutuhan individu anggota}

Setelah dialokasikan untuk kepentingan kolektif pengurus dan anggota LPD, sisa profit yang dihasilkan oleh LPD kemudian disalurkan untuk memenuhi kebutuhan individu pengurus dan anggota. Informan memberikan contoh, misalnya apabila salah satu anggota meninggal dunia, maka kebutuhan dana untuk upacara ngaben (upacara membakar mayat) dan acara-acara adat akan ditanggung oleh LPD. Dengan demikian, anggota tidak akan menanggung beban ketika dilanda kedukaan. Selain itu, ketika anggota yang meninggal dunia masih memiliki pinjaman yang belum selesai, maka LPD dengan berdasarkan pada rapat pengurus dan anggota dapat memutihkan pinjaman tersebut (menganggap pinjaman telah lunas) dan tidak membebankan pinjaman kepada ahli waris peminjam. Selain memenuhi kebutuhan untuk acara adat dan keagamaan secara individu, LPD juga menyalurkan keuntungannya kepada pengurus dan anggota dalam bentuk SHU. Komponen yang diberikan ini besarannya bergantung dari kesepakatan pengurus dan anggota. Pada masa pandemi Covid-19 saat ini, LPD dapat menjadi lumbung simpanan bagi para pengurus dan anggota. Keuntungan yang disalurkan kepada pengurus dan anggota dalam bentuk SHU dapat ditingkatkan untuk menunjang kebutuhan hidup para pengurus dan anggota. Hal menarik yang diperoleh adalah sebagian pengurus dan anggota yang merasa diri tidak terdampak pandemi Covid-19 justru cenderung untuk menunda pengambilan bagian SHU-nya dan memilih untuk mengambil kelak ketika kondisi pandemi sudah berakhir. Hal ini menjadi salah satu bentuk upaya untuk ikut menyelamatkan LPD. 
Prinsip kerja LPD untuk menghasilkan pendapatan sama dengan prinsip kerja lembaga keuangan pada umumnya, yaitu menghasilkan profit dari selisih bunga simpanan dan bunga pinjaman (Junaedi et al., 2020; Muktar, 2016). Meski demikian, LPD memiliki keunggulan yang berbentuk profit margin yang dihasilkan dapat lebih besar dibanding bank. Hal ini karena LPD tidak dibebani pajak (Pohan, 2014) dan bunga. Biaya yang menjadi pemotong pendapatan LPD sebagian besar hanya berisikan biaya operasional saja. Keuntungan yang diperoleh dari LPD kemudian digunakan untuk kesejahteraan pengurus dan anggota, baik secara kolektif maupun secara individu (Santosa \& Putri, 2018).

Peran tanggung jawab sosial makro di LPD sejalan dengan konsep corporate social responsibility (Malecki, 2018) yang dilakukan oleh perusahaan (profit oriented). Meski demikian, tanggung jawab sosial yang dilakukan oleh LPD difokuskan supaya berdampak pada pengurus dan anggotanya. Dengan demikian, pengurus dan anggota akan merasakan manfaat dari adanya LPD atau dari keanggotaannya di LPD (Junaedi et al., 2018).

Pada peran tanggung jawab sosial mikro, LPD menjalankan fungsi-fungsi seperti fungsi yang dijalankan oleh asuransi. LPD menjamin bahwa musibah yang dialami oleh pengurus dan anggota (misalnya kematian) tidak akan membebani keuangan pengurus dan anggota. Selain itu, adanya pembagian SHU membuktikan bahwa LPD menjalankan prinsip yang dimiliki oleh koperasi Raiffeisen.

Dari berbagai peran yang dilakukan tersebut, penelitian ini tidak menemukan peran edukasi seperti yang dilaksanakan dalam koperasi credit union (Unda, 2015). Informan-informan penelitian ini menyebutkan bahwa belum ada edukasi yang dilakukan oleh LPD kepada para pengurus dan anggota. Hal inilah yang membedakan LPD dengan credit union, yang mana koperasi ini menyelenggarakan kegiatan edukasi pada pengurus dan anggota dalam bentuk pelatihan literasi keuangan, pendampingan usaha, dan sebagainya.

\section{SIMPULAN DAN SARAN}

Berdasarkan penelitian yang telah dilakukan, disimpulkan bahwa terdapat tiga peran utama LPD bagi anggotanya pada masa pandemi Covid-19. Pertama adalah peran produktif, yaitu solusi keuangan bagi anggota berbasis asas kekeluargaan. Kedua adalah peran tanggung jawab sosial makro, yaitu sumber pendanaan bagi kebutuhan kolektif anggota. Ketiga adalah peran tanggung jawab sosial mikro, yaitu sumber pendanaan bagi kebutuhan individu anggota.

Berdasarkan simpulan tersebut, maka direkomendasikan kepada pengelola LPD untuk terus menjalankan LPD dengan sebaik-baiknya. Untuk pengurus dan anggota LPD yang tidak terdampak Covid-19, disarankan untuk mencurahkan perhatian dan dukungan dana yang lebih banyak untuk mendukung LPD supaya tetap dapat beroperasi dengan baik. Selain itu, perlu dilakukan peran edukasi bagi pengurus dan anggota untuk menghadapi situasi-situasi sulit, termasuk adanya pandemi Covid19.

\section{ACKNOWLEDGEMENTS}

Terima kasih kepada Kementrian Ristek BRIN yang telah mendanai penelitian kami dengan skema penelitian terapan berjudul Model Pemberdayaan Ekonomi Masyarakat Adat sebagai Strategi Dalam Percepatan Pembangunan Ekonomi Nasional dari tahun 2019 sampai 2021.

\section{REFERENSI}

Bali Bank News. (2020, 4 Agustus). Pandemi Covid-19 tak pengaruhi aset LPD Blangsinga, hingga Juli 2020 mencapai $R p$ 27,1 Miliar. http://balibanknews.com/read/202008050001/pandemicovid-19-tak-pengaruhi-aset-lpd-blangsinga-hingga-juli-2020-mencapai-rp-27-1-miliar.html

Darmayani, L. T., Julianto, I. P., \& Atmadja, A. W. T. (2017). Fidusia sebagai jaminan dalam pemberian kredit cepat untuk upacara ngaben di LPD Sumberkima. Jurnal Ilmiah Mahasiswa 
Akuntansi

Undiksha,

$8(2)$,

$1-12$.

https://ejournal.undiksha.ac.id/index.php/S1ak/article/view/14799

Farid, M., \& Adib, H. M. (2018). Fenomenologi dalam penelitian ilmu sosial. Prenada Media

Hashimoto, Y., \& Krogstrup, S. (2019). Capital flows: The role of bank and nonbank balance sheets. international monetary https://www.imf.org/en/Publications/WP/Issues/2019/04/29/Capital-Flows-The-Role-of-Bankand-Nonbank-Balance-Sheets-46731

Hennink, M., Hutter, I., \& Bailey, A. (2020). Qualitative research methods. Sage Publication

Junaedi, I. W. R., Damayana, I. W., Waruwu, D., \& Utama, I. G. B. R. (2020). Manajemen kewirausahaan adat: Transformasi usaha dan peranan lembaga keuangan tradisional. Brilian Internasional

Junaedi, I. W. R., Damayana, I. W., \& Waruwu, D. (2018). LPD model and function in increasing the indigeneous Bali economy. Proceedings International Conference on Fundamental and Applied Research, 51-62. https://jurnal.undhirabali.ac.id/index.php/icfar/article/view/901

Kaltenborn, W. (2018). Raiffeisen: Beginning and end. Zentralkonsum eG

Malecki, C. (2018). Corporate social responsibility: Perspective for sustainable corporate social governance. Edward Elgar

Muktar, B. (2016). Bank dan lembaga keuangan lain. Kencana

Nassiri, A. (2020). The lending and secured finance review. The Law Review

Perda Bali. (2017). Peraturan daerah Provinsi Bali nomor 3 tahun 2017 tentang lembaga perkreditan desa. https://jdih.baliprov.go.id/produk-hukum/peraturan/abstrak/24227

Pindyck, R. S., \& Rubinfeld, D. L. (2018). Microeconomics. Pearson

Pohan, C. A. (2014). Manajemen perpajakan: Strategi perencanaan pajak dan bisnis. Gramedia Pustaka Utama

Putrayasa, P. A. (2018). Perlakuan akuntansi terhadap penerimaan dan pengeluaran kas pada LPD (Lembaga Perkreditan Desa) Pakraman Dharmajati Tukadmungga. Jurnal Akuntansi Profesi, 9(2), 57-61. https://ejournal.undiksha.ac.id/index.php/JAP/article/view/21032

Santosa, D. S. S., \& Putri, I. Y. (2018). Peran koperasi unit desa dalam kegiatan usaha masyarakat. Firm Journal of Management Studies, $3(2), \quad$ 188-189. https://www.researchgate.net/publication/334280265_Peran_Koperasi_Unit_Desa_Dalam_Kegia tan_Usaha_Masyarakat

Sarifah. (2019). Analisa pengendalian internal dalam pemberian kredit pada Lembaga Perkreditan Desa (LPD) Desa Pakraman Tulangnyuh Cabang Klungkung. Jurnal Pendidikan Ekonomi Undiksha, 10(2), 460-469. https://ejournal.undiksha.ac.id/index.php/JJPE/article/view/20083

Satria, I. G. A., \& Parwata, A. A. G. O. (2018). Analisis hukum tentang pengawasan Lembaga Perkreditan Desa (LPD) oleh Pemerintah Kota Denpasar. Jurnal Kertha Negara, 6(4), 1-14. https://ojs.unud.ac.id/index.php/Kerthanegara/article/view/42084

Sattar. (2017). Buku ajar ekonomi koperasi. Deepublish

Soekanto. (2005). Sosiologi: Suatu pengantar. Raja Grafindo Persada

Staker, F. (2018). The money market. Routledge

Sugiyono. (2011). Metode penelitian pendidikan pendekatan kuantitatif, kualitatif, dan R\&D. Alfabeta

Todaro, M. P., \& Smith, S. C. (2012). Economic development (12 ed). Pearson

Unda, L. A. (2015). Board of directors' characteristics and credit union financial performance: A pitch. Accounting and Finance, 55(2), 353-360. Diperoleh dari https://www.usd.ac.id/fakultas/ekonomi/mmusd/f113/Artikel\%202_\%20Unda\%202015\%20Boar $\mathrm{d} \% 20 \mathrm{of} \% 20$ directors $\% 20$ charateristics $\% 20$ and $\% 20$ credit $\% 20$ union $\% 20$ financial\%20performanc e\%20-\%20a\%20pitc.pdf

Waruwu, D. (2018). Bawomataluo destinasi wisata Nias pulau impian. Deepublish

Wedayani, N. W., \& Jati, I. K. (2012). Efektivitas fungsi badan pengawas sebagai internal auditor dalam pengawasan terhadap pemberian kredit pada LPD di Kecamatan Rendang, Selat, Sidemen, dan Manggis Kabupaten Karangasem, Provinsi Bali. Jurnal Ilmiah Akuntansi dan Humanika, 1(2), 91-111. https://ejournal.undiksha.ac.id/index.php/JJA/article/view/324

Widyastuti, N. K., Waruwu, D., \& Suartana, I (2017). Pariwisata spiritual: Daya tarik wisata Palasari Bali. Pustaka Larasan 
Jurnal Manajemen Maranatha — Vol. 20 Nomor 2, Mei (2021) 